\title{
Handelshochschule Berlin.
}

\section{Vorlesungen und Übungen}

\section{im Sommer-Semester I909.}

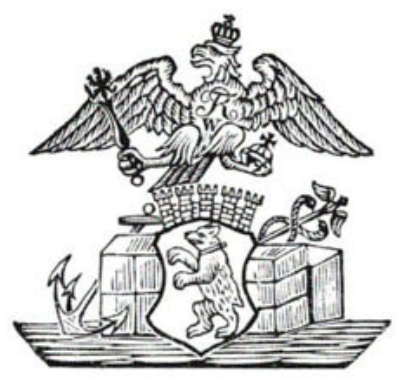

Preis 30 Pf $\mathrm{Zu}$ haben beim Pedell in der Pfortner-Loge des Hochschulgebäudes (am Eingang Spandauerstr.1). 